5

\title{
Pengembangan Sistem Audit Sosial untuk Mengevaluasi Kinerja Layanan Pemberdayaan Sosial
}

\author{
Pudji Muljono, Saharuddin, dan Martua Sihaloho ${ }^{1}$ \\ Ringkasan
}

Audit sosial merupakan kerangka kerja yang memungkinkan sebuah organisasi memiliki dokumentasi, laporan dan menyusun sebuah proses yang dapat menghitung kinerja sosial, melaporkan kinerja dan menciptakan sebuah rencana aksi untuk mengembangkan kinerja tersebut, sampai kepada aspek pemahaman dampak pada masyarakat dan dapat dipertanggungjawabkan kepada stakeholders. Tujuan penulisan ini adalah untuk menyajikan hasil pengembangan sistem audit sosial yang diharapkan dapat digunakan sebagai acuan untuk menilai kinerja pelaksanaan program/kegiatan yang berlangsung di lingkup Departemen Sosial RI. Lokasi uji coba pengembangan sistem audit sosial adalah pada 6 (enam) provinsi yaitu Provinsi Bengkulu, Banten, Jawa Tengah, Kalimantan Timur, Sulawesi Tenggara, dan Sulawesi Selatan.

Hasil kajian menunjukkan bahwa kinerja program layanan sosial bervariasi antara satu daerah atau lokasi dengan daerah atau lokasi lainnya. Rekomendasi yang diajukan dari kajian ini adalah bahwa untuk mendukung implementasi sistem audit sosial perlu dikeluarkan seperangkat regulasi di tingkat kementrian berupa Keppmen, sehingga penerapan sistem audit sosial lebih bersifat mengikat dan pedoman operasional atau pedoman teknis terkait. Selain itu perlu upaya pengembangan sumberdaya manusia yang akan mengelola sistem audit sosial tersebut pada lingkup dinas sosial provinsi atau kab/kota dan PSKS/komunitas, misalnya melalui pendidikan dan pelatihan, workshop, seminar, dan sebagainya.

Katakunci : sistem audit sosial, evaluasi kinerja layanan, pemberdayaan sosial

\section{Pendahuluan}

\subsection{Latar Belakang}

Saat ini bangsa Indonesia sedang dihadapkan paling tidak kepada dua tantangan yang cukup berat, yaitu (1) adanya kebijaksanaan otonomi daerah (desentralisasi) yang sudah digulirkan dan (2) tantangan era globalisasi yang akan terjadi pada tahun 2020. Kedua tantangan tersebut memiliki implikasi terhadap permasalahan sosial kemasyarakatan, terutama pada kelompok masyarakat penyandang masalah sosial, berkenaan dengan mekanisme dan

\footnotetext{
${ }^{1}$ Staf Pengajar Departemen Komunikasi dan Pengembangan Masyarakat

Fakultas Ekologi Manusia - Institut Pertanian Bogor
} 
kualitas layanan yang mereka terima. Untuk mengantisipasi kekhawatiran tersebut maka institusi pelayanan dan pengelola kegiatan sosial diharapkan mampu menangani kegiatan secara lebih profesional yang ditunjukkan dengan adanya kinerja optimal dan dapat memberikan manfaat seluas-luasnya bagi masyarakat pengguna.

Salah satu harapan utama masyarakat adalah mendapatkan manfaat optimal dari program pembangunan baik manfaat sosial maupun ekonomi, yang ditujukan untuk diri mereka maupun lingkungan. Keberlanjutan keuntungan ekonomi merupakan hal penting, tetapi manfaat sosial tidak dapat diabaikan meskipun pada kenyataannya sulit mencapai keduanya sekaligus. Yang sering terjadi justru manfaat sosial terpinggirkan oleh keuntungan-keuntungan ekonomi. Terkadang juga program pembangunan menghasilkan manfaat sosial dan ekonomi yang tidak dirancang sebelumnya, sekalipun tujuan yang dinyatakan secara tegas tak tercapai sepenuhnya atau bahkan tak terwujud. Proses audit sosial dapat digunakan sebagai masukan dalam melihat dan menilai hasil-hasil pembangunan secara optimal, karena audit sosial mencakup penilaian aspek prosedur, pencapaian tujuan dan sekaligus penggambaran manfaat program secara komprehensif.

Setiap program dirancang untuk memecahkan masalah yang menyangkut kebutuhan masyarakat atau stakeholders secara berkesinambungan dan memiliki daya jangkau yang luas, tidak terbatas pada hasil-hasil yang dicapai sesaat. Artinya diperlukan penilaian terhadap suatu program secara berkesinambungan dan tidak terbatas pada tercapainya target-target yang dinyatakan dalam pernyataan tujuan, melainkan juga harus diukur pada ekspresi Pencapaian manfaat dari perspektif masyarakat. Audit sosial merupakan kerangka kerja yang memungkinkan sebuah organisasi memiliki dokumentasi, laporan dan menyusun sebuah proses yang dapat menghitung kinerja sosial, melaporkan kinerja dan menciptakan sebuah rencana aksi untuk mengembangkan kinerja tersebut, sampai kepada aspek pemahaman dampak pada masyarakat dan dapat dipertanggungjawabkan kepada stakeholders. Prinsip audit sosial adalah untuk mencapai peningkatan kinerja secara terusmenerus terhadap sasaran hasil sosial yang telah dipilih dan ditetapkan sebelumnya.

Departemen Sosial RI sebagai lembaga yang memiliki legitimasi dan kompetensi untuk menjalankan dan melakukan penilaian terhadap programprogram pembangunan, khususnya terhadap program-program pembangunan yang menyangkut, memecahkan dan menghasilkan masalah-masalah sosial baru. Oleh karena itu, khususnya dalam pengelolaan kegiatan sosial yang ada di masyarakat, audit sosial dapat menjadi instrumen pokok dalam pengukuran kinerja dan pencapaian sasaran programnya. 


\subsection{Tujuan}

Hasil pengembangan sistem audit sosial ini dapat digunakan sebagai acuan untuk menilai kinerja pelaksanaan program/kegiatan yang berlangsung di lingkup Departemen Sosial RI. Oleh karena itu, secara khusus tujuan kegiatan ini adalah:

1. Menentukan tingkat kinerja sosial program pemberdayaan Penyandang Masalah Kesejahteraan Sosial (PMKS), Departemen Sosial RI,

2. Menyusun sistem audit sosial bagi penyelenggaraan program/kegiatan yang dikelola oleh Departemen Sosial RI.

3. Menentukan kriteria dan indikator kinerja untuk kegiatan audit sosial bagi program pemberdayaan PMKS di Departemen Sosial RI.

\subsection{Manfaat}

Kegiatan audit sosial menghasilkan suatu keluaran yang sangat penting untuk mengetahui kinerja dan hasil seluruh kegiatan yang telah berlangsung. Adapun manfaat audit sosial di lingkungan program pemberdayaan PMKS adalah:

1. Memberikan informasi secara kualitatif dan kuantitatif program secara komprehensif tentang program pemberdayaan PMKS,

2. Membuka ruang pertanggungjawaban penyelenggaraan program bagi stakeholders melalui hasil publikasi yang telah dikerjakan, bagaimana melakukan, bagaimana membiayai, bagaimana bekerja dalam kemitraan dan untuk memahami asal-usul nilai tambah yang dicapai.

3. Menyediakan proses penyelenggaraan program yang fleksibel dan dapat diadaptasikan,

4. Mendorong adanya penilaian organisasi internal dan eksternal yang jujur, dan

5. Mengarah pada terwujudnya konsistensi penyelenggaraan program melalui kegiatan audit.

\section{Tinjauan Konseptual}

\subsection{Konsep Audit Sosial}

Konsep atau istilah audit sosial mulai dikenal tahun 1960 oleh The Social Economic Agency (Northern Ireland) saat mengadakan pelatihan kepada 10 organisasi untuk melatih para auditor lembaga maupun konsultan eksternal agar dapat menerapkan dan memanfaatkan metode audit sosial ini. Beberapa pakar mendefinisikan pengertian audit sosial, antara lain:

- Social auditing is a process that enables an organization to assess and demonstrate its social, economic, and environmental benefit and limitations. It is a way of measuring the extent to which an organization lives up to the shared 
values and objective it has committed it self to. Social auditing provides an assessment of the impact of an organization's non financial objectives through systematically and regularly monitoring, each performance and the views of its stakeholders (Boyd, 1998).

- Social auditing is the process whereby an organization can account for its social performance, report on and improve that performance. Social auditing assesses the social impact and behaviour of an organization in relation to its aims (Pierce and Kays, 2001 dalam Anonim, 2005).

- The social audit process provides a tool for organizations to use, if they choose so, to measure how well they are achieving their social objectives. It is a way of more accurately describing what you as an organization are achieving. It allows you to demonstrate to others what you are and what you do (Pierce and Kays, 2001 dalam Anonim, 2005).

Berdasarkan beberapa definisi tersebut, dapat ditegaskan bahwa konsep audit sosial mengandung pengertian sebagai proses untuk memahami dan mengukur institutional performances dari aspek sosial (non finansial). Audit sosial dapat memperlihatkan hasil nyata (outcome), dampak dan manfaat lembaga terhadap lingkungan sosial yang muncul sebagai akibat pelaksanaan pencapaian tujuan lembaga melalui pemantauan yang sistematik dan pandangan stakeholders secara demokratis. Boyd (1998) menyatakan : social auditing requires the involvement of stakeholders because it has been shown to increase accountability of the organization to its stakeholders and to enhance democratic practice.

\subsection{Prinsip Pendekatan dan Manfaat Audit Sosial}

Audit sosial merupakan salah satu bidang dalam ilmu sosial terapan yang penting dalam pembangunan, terutama untuk memberdayakan masyarakat. Proses audit sosial menyediakan alat yang dapat digunakan oleh organisasi untuk menjamin ketepatan mencapai tujuan sosial. Dengan kata lain audit bukanlah tujuan melainkan suatu instrumen untuk mencapai tujuan yaitu mencari nilai manfaat (goal oriented process). Ini merupakan cara akurat untuk menggambarkan apa yang telah dicapai oleh suatu lembaga. Juga dapat menuntun organisasi untuk menjelaskan mengapa, siapa dan apa (kebijakan maupun tindakan) yang dilakukan oleh lembaga.

Pelaksanaan audit sosial selalu melibatkan stakeholders agar proses demokrasi terwujud dan untuk meningkatkan akuntabilitas lembaga. Berdasarkan kerangka ketatanegaraan, ada tiga jenis akuntabilitas yaitu democratic accountability, professional accountability dan legal accountability. Audit sosial merupakan upaya untuk menjawab akuntabilitas berdasarkan kepuasan stakeholders dan staf, selain dari aspek finansial, aspek operasi kegiatan internal, dan aspek waktu. Tabel 1 berikut ini memperlihatkan prinsip-prinsip pendekatan pelaksanaan audit sosial dan manfaatnya. 


\begin{tabular}{|c|c|}
\hline Prinsip Pendekatan & Manfaat \\
\hline $\begin{array}{l}\text { - Multi-perspective, bahwa opini yang didapat harus } \\
\text { dari berbagai sumber yang luas (keseluruhan } \\
\text { stakeholders), baik yang mempengaruhi maupun } \\
\text { yang dipengaruhi atau terkena dampak } \\
\text { organisasi/lembaga } \\
\text { - Comprehensive, bahwa laporan yang dihasilkan } \\
\text { harus meliputi seluruh aspek dan aktivitas } \\
\text { lembaga tersebut } \\
\text { - Comparative, bahwa organisasi pelayanan } \\
\text { masyarakat harus selalu meningkatkan pelayanan } \\
\text { dengan mengadakan perbandingan performance } \\
\text { lembaga dengan organisasi lain dari waktu ke } \\
\text { waktu } \\
\text { - Regular, yakni diupayakan berjalan setiap tahun } \\
\text { dan bukan one-off exercise, bertujuan } \\
\text { menghasilkan social account berdasar pada konsep } \\
\text { dan pelaksanaan melekat sebagai budaya } \\
\text { organisasi/lembaga tersebut } \\
\text { Verified, bahwa laporan pelaksanaan kegiatan } \\
\text { (social account) harus dilihat oleh orang luar } \\
\text { (independent person), untuk menjamin bahwa } \\
\text { pelaksanaan social account diaudit oleh seseorang } \\
\text { yang tidak memiliki ketertarikan pribadi } \\
\text { terhadap lembaga tersebut } \\
\text { - Disclosed, bahwa pelaksanaan audit sosial } \\
\text { memiliki ruang lingkup yang luas untuk } \\
\text { menjamin keterbukaan kepada stakeholders dan } \\
\text { komunitas yang lebih luas yang memiliki } \\
\text { perhatian pada akuntabilitas dan transparansi }\end{array}$ & $\begin{array}{l}\text { - Memiliki definisi yang tajam } \\
\text { dan fokus dalam lembaga } \\
\text { - Memberikan } \\
\text { pertanggungjawaban } \\
\text { kepada stakeholders } \\
\text { - Menyediakan kerangka kerja } \\
\text { yang bermanfaat untuk } \\
\text { semua aktivitas lembaga } \\
\text { - Memberikan kepercayaan } \\
\text { untuk memperoleh outcome } \\
\text { yang tepat } \\
\text { - Menjamin lingkungannya } \\
\text { untuk dapat merasakan } \\
\text { manfaat keberadaan lembaga } \\
\text { tersebut } \\
\text { - Melibatkan stakeholders dalam } \\
\text { setiap kegiatan lembaga } \\
\text { Menyediakan proses yang } \\
\text { fleksibel dan penilaian } \\
\text { internal maupun eksternal } \\
\text { yang jujur sehingga dapat } \\
\text { mendorong konsistensi } \\
\text { lembaga tersebut }\end{array}$ \\
\hline
\end{tabular}

Sumber : John Pearce dan Alan Kay (2001 dalam Anonim, 2005)

Institusi dan organisasi sosial dalam mengadakan audit sosial, biasanya didasarkan pada beberapa alasan, antara lain :

1) keinginan membentuk community enterprise yang menyediakan pelayanan masyarakat sehingga perlu menetapkan performance seperti apa yang diinginkan;

2) dapat menguji opini orang lain sehingga dapat membantu perencanaan selanjutnya;

3) dapat memberikan data kualitatif dan kuantitatif untuk menuntun organisasi sehingga memberikan performance terbaik;

4) memberikan gambaran obyektif kegiatan yang dilakukan lembaga dan memaparkan keunikan dan keberhasilan lembaga tersebut sebagai bukti pertanggungjawaban kepada lembaga donor maupun kepada masyarakat sebagai penerima manfaat program; keinginan untuk menerapkan nilai sebagai agent of change di dalam masyarakat serta mencari ide atau cara baru. 
Pencapaian tujuan organisasi; keinginan memeriksa apa yang telah diraih lembaga; membuktikan kepada masyarakat luas bahwa lembaga ini tetap eksis.

Tahapan audit sosial menurut Alan Kay (2001 dalam Anonim, 2005) adalah :

1) mengumpulkan bahan dan mempersiapkan proses audit sosial;

2) menentukan tujuan pelaksanaan audit sosial, membuat daftar stakeholders;

3) menentukan indikator yang akan digunakan untuk mengukur performance lembaga;

4) mempersiapkan social book-keeping, yakni informasi yang secara rutin dikumpulkan untuk menggambarkan performance lembaga tersebut dalam kaitannya dengan Pencapaian tujuan sosial (social objectives);

5) mempersiapkan social accounts, yakni dokumen yang dihasilkan dari proses social accounting yang mengukur performance lembaga kualitatif maupun kuantitatif;

6) menguraikan dan menjabarkan informasi yang terdapat dalam social accounts dan mengadakan wawancara dengan stakeholders;

7) menyusun laporan audit sosial.

\subsection{Program dan Strategi Audit Sosial}

Audit sosial jangka panjang merupakan kegiatan yang berpotensi menguntungkan stakeholders apabila dilihat dari sisi kepentingan memelihara kestabilan dan kesinambungan pembangunan. Di sisi lain, keberadaan kegiatan dari setiap proyek pembangunan sewajarnya dapat dimanfaatkan dan dirasakan langsung oleh masyarakat setempat. Artinya, setiap kegiatan dapat menumbuhkembangkan keharmonian dengan masyarakat sekitar, mencegah timbulnya konflik, seperti apabila kehadiran proyek pembangunan tidak mempunyai manfaat langsung bagi masyarakat bersangkutan; dan sekaligus dapat memperkuat rasa memiliki masyarakat terhadap proyek pembangunan. Kondisi ini dapat mencegah terjadinya kesenjangan komunikasi berbagai bidang, membantu menetapkan standar perencanaan pembangunan yang lebih terarah, akhirnya dapat mengembangkan program pembangunan baru.

Strategi audit sosial pada dasarnya bermula dari program "apa yang dikehendaki (menjadi keinginan) masyarakat". Hal ini hanya diketahui oleh masyarakat itu sendiri, terutama tentang perlunya upaya memperbaiki "pembuatan keputusan bersama" antara masyarakat dengan pemrakarsa sampai kepada bagaimana kesejahteraan masyarakat diwujudkan. Berdasarkan hal ini, maka pemrakarsa perlu dan harus mengkaji, "apa sebenarnya yang diinginkan masyarakat sekitar proyeknya", bukan sebaliknya, kegiatan proyek pembangunan dibuat atas dasar "keinginan dan selera" pemrakarsa. Karena itu, masyarakatlah yang perlu diutamakan dalam menentukan segala keinginannya dalam suatu perencanaan pembangunan.

Program audit sosial yang perlu dilakukan di antaranya melalui penelitian, pemantauan dan evaluasi, bertujuan untuk menguji atau menilai pelayanan 
program (program inputs and outcomes) secara sistematik, mempersiapkan laporan periodik mengenai bagaimana cara kegiatan program berfungsi dan dilaksanakan. Auditor dalam hal ini, membantu pemrakarsa dalam merancang recording dan prosedur mengevaluasi kebutuhan pembangunan secara rutin. Metode yang digunakan adalah dengan mengumpulkan data primer dan sekunder dengan menggunakan alat/instrumen terstruktur (kuesioner, pedoman wawancara dan pengamatan di lapangan). Sasaran dan kegiatan yang diaudit disajikan pada Tabel 2 berikut ini.

Tabel 2. Sasaran dan Kegiatan Audit Sosial (Anonim, 2002)

\begin{tabular}{|c|c|}
\hline Sasaran Audit & Kegiatan yang Diaudit \\
\hline $\begin{array}{l}\text { Semua bentuk dan kegiatan } \\
\text { pembangunan (relevant } \\
\text { information and actual state } \\
\text { program) }\end{array}$ & $\begin{array}{l}\text { - Profil klien yang dilibatkan dalam program } \\
\text { - Ringkasan program yang diberikan } \\
\text { - Beban kerja staf yang bertugas } \\
\text { - Rencana yang pernah disusun dan yang dapat } \\
\text { direalisasikan } \\
\text { - Hasil kegiatan dalam setiap tahun }\end{array}$ \\
\hline $\begin{array}{l}\text { Petugas yang melaksanakan } \\
\text { kegiatan pembangunan (the } \\
\text { providers of services) }\end{array}$ & $\begin{array}{l}\text { - Penilaian terhadap semua kegiatan yang telah } \\
\text { dikerjakan } \\
\text { - Perasaan kepuasan dan ketidakpuasan }\end{array}$ \\
\hline $\begin{array}{l}\text { Klien (masyarakat) yang } \\
\text { terlibat kegiatan (the clients } \\
\text { of program participants) }\end{array}$ & $\begin{array}{l}\text { - Penilaian terhadap semua kegiatan yang telah } \\
\text { diterima } \\
\text { - Perasaan kepuasan dan ketidakpuasan }\end{array}$ \\
\hline $\begin{array}{l}\text { Masyarakat sekitar yang } \\
\text { tidak atau belum terlibat }\end{array}$ & $\begin{array}{l}\text { - Penilaian terhadap semua kegiatan yang telah } \\
\text { diketahui } \\
\text { - Perasaan kepuasan dan ketidakpuasan }\end{array}$ \\
\hline
\end{tabular}

\subsection{Lingkup Audit Sosial}

Lingkup audit sosial meliputi dua aspek yaitu aspek individu dan aspek kelembagaan. Audit sosial tingkat individu lebih bersifat pada penelaahan sifat atau perilaku personal dalam menjalankan perannya dalam komunitas, bagaimana seseorang diposisikan dan kemungkinannya untuk berkembang dengan memanfaatkan fasilitas atau sumberdaya yang disediakan melalui program dan/atau sumberdaya yang ada. Pada tingkat operasional tercermin pada perilaku aparat pemrakarsa proyek dan petugas lapangan, peserta program dan warga lain yang bukan peserta.

Audit sosial pada tingkat kelembagaan menelaah aspek saling mempengaruhi antara komponen program dan aspek kelembagaan yang antara lain dapat dilihat pada bagaimana program diapresiasi oleh kelembagaan dan organisasi setempat, hasil, manfaat dan dampak program terhadap kelembagaan dan organisasi setempat dan sebaliknya bagaimana lingkungan kelembagaan mempengaruhi keberlangsungan dan keberhasilan program, yang dapat ditelaah dari aturan dan nilai yang dibangun lembaga pelaksana program dan nilai yang berkembang pada organisasi masyarakat setempat. Karena individu 
diasumsikan ada pada setiap organisasi kelembagaan dalam rangka pelaksanaan program tersebut, maka organisasi juga menjadi wadah bagi individu-individu yang memanfaatkan program untuk melakukan aktivitasnya.

\subsection{Dimensi Program dan Lingkup Studi Audit Sosial}

Program sosial yang diaudit adalah program pemberdayaan 27 kategori PMKS. Rentang permasalahan dan kategori sosial peserta sangat banyak, sehingga diperlukan satu alat penyederhanaan, dalam studi ini digunakan kerangka logis (logical framework) yang menyangkut: tujuan, manfaat, hasil, proses, kegiatan dan input kegiatan, dimana masing-masing aspek memiliki indikator sendiri. Secara sederhana kerangka logis tersebut dapat disajikan pada Tabel 3.

Tabel 3. Dimensi Program PMKS dan Lingkup Studi Audit Sosial

\begin{tabular}{|c|c|c|c|c|}
\hline \multirow{2}{*}{ No } & \multirow{2}{*}{$\begin{array}{l}\text { Dimensi } \\
\text { Program } \\
\text { PMKS }\end{array}$} & \multirow{2}{*}{ Indikator } & \multicolumn{2}{|c|}{ Lingkup Studi Audit Sosial } \\
\hline & & & Individu & Komunitas \\
\hline 1. & $\begin{array}{l}\text { Pencapaian } \\
\text { Tujuan }\end{array}$ & $\begin{array}{l}\text { Persepsi aktor tentang } \\
\text { Pencapaian unsur- } \\
\text { unsur tujuan program } \\
\text { seperti yang diketahui } \\
\text { oleh } \\
\text { responden/informan. }\end{array}$ & $\begin{array}{l}\text { 1) Tingkat kualitas } \\
\text { hidup individu/ } \\
\text { keluarga }\end{array}$ & $\begin{array}{l}\text { 1) Tingkat } \\
\text { kesejahteraan } \\
\text { komunitas }\end{array}$ \\
\hline 2. & Manfaat & $\begin{array}{l}\text { Perubahan-perubahan } \\
\text { yang dicapai dari } \\
\text { hasil-hasil program }\end{array}$ & $\begin{array}{l}\text { 2) Peningkatan } \\
\text { komponen } \\
\text { kualitas hidup } \\
\text { individu dan } \\
\text { keluarga }\end{array}$ & $\begin{array}{l}\text { 2) Nilai-nilai } \\
\text { organisasi dan } \\
\text { kelembagaan } \\
\text { program yang } \\
\text { bersifat } \\
\text { mengikat bagi } \\
\text { masyarakat }\end{array}$ \\
\hline 3. & Hasil & $\begin{array}{l}\text { Nilai material atau } \\
\text { nilai-nilai sosial yang } \\
\text { muncul dan/atau } \\
\text { berubah dan } \\
\text { dinyatakan oleh aktor }\end{array}$ & $\begin{array}{l}\text { 3) Unsur-unsur } \\
\text { materi yang } \\
\text { diperoleh dari } \\
\text { keterlibatannya } \\
\text { dalam program }\end{array}$ & $\begin{array}{l}\text { 3) Unsur-unsur } \\
\text { materiil yang } \\
\text { diperoleh } \\
\text { komunitas/yang } \\
\text { dinikmati secara } \\
\text { kolektif dari } \\
\text { program }\end{array}$ \\
\hline 4. & Proses & $\begin{array}{l}\text { Mekanisme yang } \\
\text { dibangun membuka } \\
\text { ruang partisipasi }> \\
\text { program lain dan/atau } \\
\text { program yang pernah } \\
\text { dialami sebelumnya. }\end{array}$ & $\begin{array}{l}\text { 4) Tindakan- } \\
\text { tindakan } \\
\text { individu dalam } \\
\text { usaha } \\
\text { mengakses } \\
\text { program dan } \\
\text { hak-haknya atas } \\
\text { program } \\
\text { tersebut }\end{array}$ & $\begin{array}{l}\text { 4) Bentuk-bentuk } \\
\text { organisasi dan } \\
\text { kelembagaan } \\
\text { yang menjadi } \\
\text { acuan bagi } \\
\text { penyelenggaraan } \\
\text { program }\end{array}$ \\
\hline 5. & Input & Input dari program & 5) Kontribusi & 5) Kontribusi \\
\hline
\end{tabular}




\begin{tabular}{|l|l|l|l|l|}
\hline & & $\begin{array}{l}\text { mudah diakses oleh } \\
\text { aktor }\end{array}$ & \multicolumn{1}{|c|}{$\begin{array}{l}\text { individu dalam } \\
\text { program }\end{array}$} & $\begin{array}{l}\text { komunitas } \\
\text { dalam program }\end{array}$ \\
\hline 6. & Kegiatan & $\begin{array}{l}\text { Kegiatan yang dilaksanakan sesuai dengan aspirasi aktor dan } \\
\text { potensi yang dimilikinya oleh warga yang menjadi sasaran } \\
\text { program }\end{array}$ \\
\hline
\end{tabular}

\section{Metodologi}

\subsection{Lokasi Pelaksanaan Kegiatan}

Lokasi uji coba pengembangan sistem audit sosial adalah pada 6 (enam) provinsi yaitu:

1. Provinsi Bengkulu

2. Provinsi Banten

3. Provinsi Jawa Tengah

4. Provinsi Kalimantan Timur

5. Provinsi Sulawesi Tenggara, dan

6. Provinsi Sulawesi Selatan.

Dari setiap provinsi diambil kabupaten/kota yang dipilih dengan kriteria kabupaten/kota banyak program yang terkategori identik dengan program penanggulangan kessos atau sedikit penanggulangan kessos dan indeks PMKS tinggi atau rendah. Pada setiap kabupaten dipilih satu komunitas dengan PMKS terbanyak dan surplus penanggulangan kessos.

\subsection{Tahapan Kegiatan}

Proses penyusunan audit sosial perlu dilaksanakan secara transparan, partisipatif dan mengacu kepada standar baku yang telah dipersiapkan. Beberapa tahapan kegiatan yang dilakukan untuk mengembangkan sistem audit sosial adalah:

1. Brainstorming untuk menyamakan persepsi tentang sistem audit sosial dan social accounting

2. Menyusun kerangka dasar sistem audit sosial dan social accounting

3. Menyusun kriteria dan indikator kinerja kegiatan audit sosial dan social accounting

4. Menyiapkan tim ahli dan penilai lapangan untuk audit sosial dan social accounting

5. Uji coba sistem audit sosial dan social accounting

6. Analisis hasil ujicoba sistem audit sosial dan social accounting

7. Pelaporan dan presentasi.

Data hasil ujicoba audit sosial bisa digunakan berulang-ulang dalam berbagai aspek yang berbeda, tergantung tujuannya. Hal ini karena hasil audit sosial bisa mengambil gambaran secara menyeluruh tentang kinerja sebuah komunitas beserta aktivitas komponen-komponen di dalamnya. Dengan melihat gambaran yang luas, tentunya seorang peneliti bisa mengambil sebagian atau beberapa bagian darinya untuk dibahas dan disimpulkan sesuai dengan tujuan 
penelitiannya. Bahkan dengan menggunakan data tersebut bisa juga dikembangkan ke penelitian lanjutan yang lebih luas dan lebih baik lagi. Secara berurut, aktivitas dalam kegiatan audit sosial digambarkan pada Gambar 1.

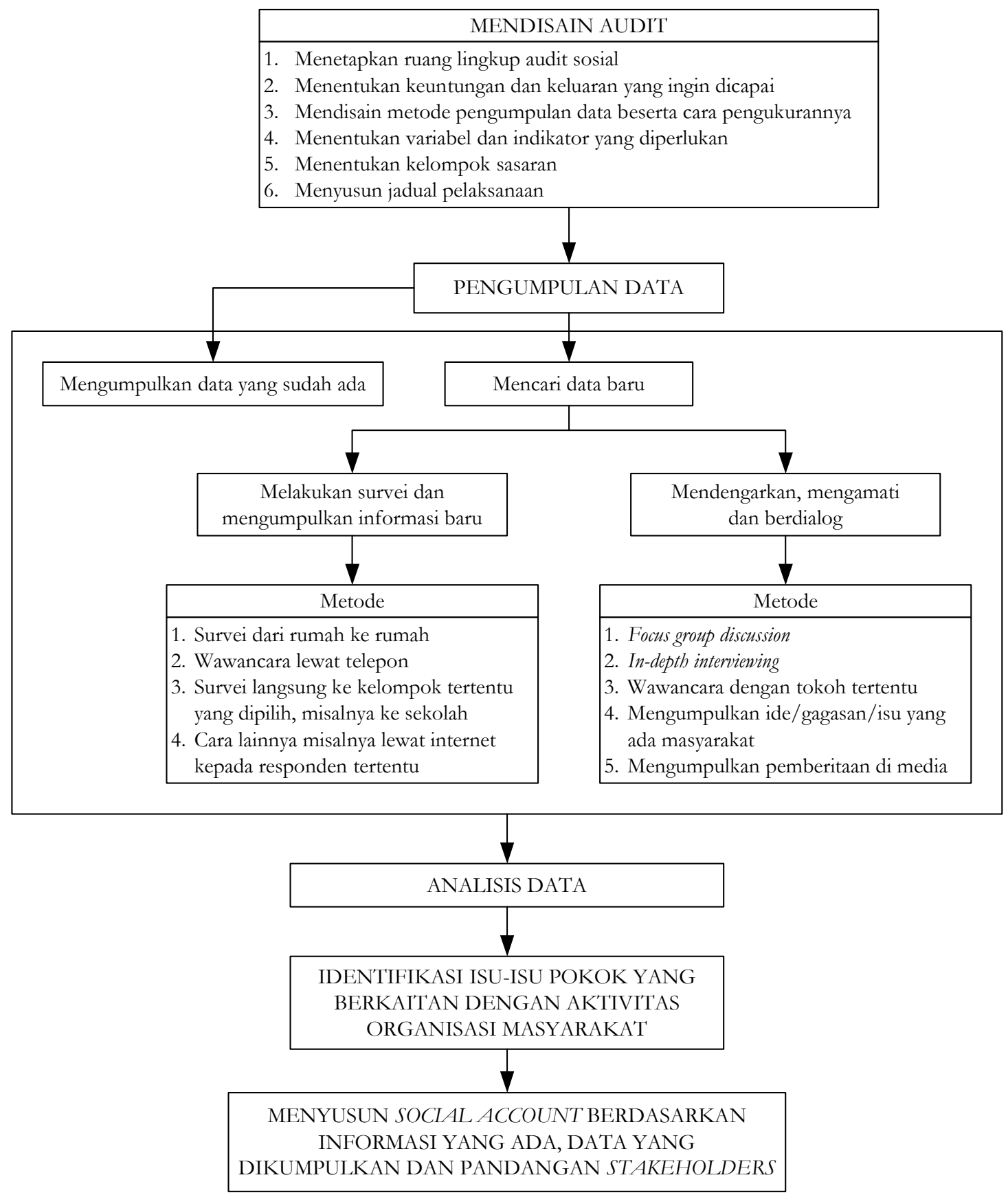

Gambar 1. Tahapan Kegiatan Audit Sosial 


\subsection{Metode Pengumpulan Data}

Terdapat beberapa metode pengumpulan data yang digunakan yaitu:

1. Focus groups: mengundang sejumlah orang yang telah diidentifikasi untuk berdiskusi dengan topik-topik khusus. Masing-masing menyampaikan gagasan dan permasalahan yang sedang didiskusikan dan kemudian ditanggapi oleh anggota kelompok yang lain.

2. In-depth interview: Melakukan wawancara mendalam dengan tokoh tertentu dapat berasal dari peserta FGD (pada waktu yang lain) atau tokoh masyarakat lain sehingga pertanyaan menjadi lebih luas dan lebih terperinci karena mengkaitkan antar jawaban pertanyaan yang satu dengan pertanyaan yang lain.

3. Survei: Melakukan wawancara kepada responden dengan menggunakan kuesioner yang telah dipersiapkan secara khusus dan sama untuk setiap kategori responden.

Selanjutnya pada setiap kabupaten/kota dilakukan pengumpulan data dengan sumber data sebagai berikut.

Tabel 4. Kebutuhan dan Sumber Data

\begin{tabular}{|c|c|c|c|}
\hline No & Sumber Data (Responden) & Jumlah & Keterangan \\
\hline 1 & Pengelola di Prov/kab/kota & $3 \times 6$ provinsi $=18$ & $\begin{array}{l}\text { Satuan lokasi sesuai pembagian } \\
\text { tugas dalam program }\end{array}$ \\
\hline 2 & $\begin{array}{l}\text { Pengelola Program di } \\
\text { Desa/Komunitas } \\
\text { (3 program/desa di kab/kota) }\end{array}$ & $6 \times 6$ provinsi $=36$ & $\begin{array}{l}3 \text { program masing-masing } 2 \text { org } \\
\text { pengelola tingkat lokal }\end{array}$ \\
\hline 3 & $\begin{array}{l}\text { Organisasi : pilih } 4 \text { orang }(2 \\
\text { lokasi) } \\
\text { - Tokoh Masyarakat ( } 1 \text { orang) } \\
\text { - Pengurus Orsos ( } 1 \text { orang) } \\
\text { - Kepala Desa ( } 1 \text { orang) } \\
\text { - Pengurus Organisasi Wanita } \\
\text { - } 1 \text { orang) } \\
\text { PSM ( } 1 \text { orang) }\end{array}$ & $8 \times 6$ provinsi $=48$ & $\begin{array}{l}\text { Satuan komunitas pada tingkat } \\
\text { mana program terlaksana }\end{array}$ \\
\hline 4 & $\begin{array}{l}\text { Rumah tangga : } \\
\text { - } \begin{array}{l}\text { Peserta }(2 \text { orang } \times 3 \\
\text { program })\end{array} \\
\text { - } \begin{array}{l}\text { Non peserta ( } 1 \text { orang per } \\
\text { kab/kota) }\end{array} \\
\end{array}$ & $\begin{array}{l}6 \times 6 \text { provinsi }=36 \\
2 \times 6 \text { provinsi }=12\end{array}$ & $\begin{array}{l}\text { Keluarga yang mendapatkan } \\
\text { program } \\
\text { Warga komunitas tempat } \\
\text { kegiatan/program berlangsung }\end{array}$ \\
\hline 5 & $\begin{array}{l}\text { Peserta program ( } 2 \text { org tiap } \\
\text { program) }\end{array}$ & $12 \times 6$ provinsi $=72$ & $\begin{array}{l}\text { Berasal dari kelompok } \\
\text { PMKS yang berbeda }\end{array}$ \\
\hline & Jumlah & 222 & $\begin{array}{l}\text { Satuan komunitas pada tingkat } \\
\text { mana program terlaksana }\end{array}$ \\
\hline
\end{tabular}




\subsection{Pemilihan Komunitas dan Program Sampel}

Lokasi penelitian adalah kabupaten/kota dimana diambil 3 (tiga) program yang dinyatakan sebagai program unggulan. Masing-masing program tersebut diambil pada desa/kelurahan/ komunitas yang berbeda dari kabupaten/kota lokasi penelitian. Hal ini dimaksudkan untuk menjaga konsistensi pengambilan data antar daerah karena kemungkinan tidak akan terdapat tiga program PMKS dalam satu desa/kelurahan/ komunitas.

Pemilihan program dibatasi pada enam program dan fokus pada tiga program PMKS unggulan pada tingkat komunitas dimaksudkan untuk: 1) menemukan indikator dan pengukuran bagi penentuan hasil audit secara efektif dan memudahkan menyusun indikator. Suatu indikator disusun dari data yang lebih lengkap dan komprehensif yang diperoleh pada program yang diunggulkan. 2) secara langsung menentukan peringkat program PMKS berdasarkan standar audit yang telah ditetapkan sesuai variabel yang telah dikumpulkan.

\subsection{Pengolahan Data}

Setelah pelaksanaan survei, data atau bahan penelitian yang dikumpulkan dianalisis dengan metode analisis data yang sesuai. Berikut ini beberapa cara yang digunakan untuk mengolah data yang telah terkumpul:

1. Untuk mengolah data secara kuantitatif digunakan bantuan software statistika yang tersedia dalam komputer. Data hasil kuesioner diberi kode, skoring dan nilai-nilai tertentu yang sesuai dengan metode statistika yang ada sehingga bisa dilakukan penghitungan dan tabulasi silang. Pengkodean dapat dilakukan dengan mengelompokkan responden atau mengelompokkan jawaban dengan kategori yang cukup mewakili.

2. Data lainnya hasil focus groups atau wawancara kelompok yang berbentuk narasi (notulensi) dilakukan analisis kualitatif dengan cara mengelompokkan dan mengkategorikan isu-isu pokok yang muncul. Hal ini menuntut perhatian peneliti yang tinggi berdasarkan pengetahuan dan pengalamannya.

3. Penggabungan Hasil. Proses penggabungan hasil penelitian adalah sebagai berikut:

a. Mengumpulkan data eksternal, dengan melakukan cek ulang untuk meneliti kebenaran data tersebut

b. Mendiskusikan dan mengamati isu-isu yang berkaitan dengan ide, peristiwa lingkungan yang muncul misalnya: kejahatan, anak jalanan dan lain-lain.

c. Melihat sejumlah perubahan yang terjadi, kemudian mentabulasikan dalam kelompok atau pengamatan

d. Menemukan identitas kelompok (informal) dengan memperhatikan karakteristik misalnya usia, pekerjaan, pendidikan dan lain-lain. 
e. Mendeskripsikan dengan menggunakan tulisan yang rinci.

\section{Pengembangan Sistem Audit Sosial}

\subsection{Tahap Pengembangan Sistem}

Pengembangan sistem audit sosial diawali dengan penyamaan persepsi di antara para pendisain atau pengkaji sistem audit dan para stakeholder terutama dari instansi Departemen Sosial RI. Penyamaan persepsi tentang audit sosial telah dilakukan sejak beberapa waktu yang lalu, baik melalui pertemuan formal disertai diskusi, wawancara mendalam, kajian dokumen, maupun melalui jalur komunikasi dan informasi lainnya misalnya melalui telepon, internet, suratmenyurat, dan sebagainya. Mengacu pada proses penyamaan persepsi yang telah dilaksanakan, kemudian disepakati antara lain bahwa audit sosial sedapat mungkin mampu mengkaji sejauh mana kinerja program pelayanan sosial yang telah diterima oleh sebanyak 27 PMKS.

Mengingat begitu banyaknya program pelayanan sosial dan juga bervariasinya penerima manfaat kesejahteraan sosial, maka untuk tahap awal pengembangan sistem audit ini hanya dilakukan ujicoba terhadap beberapa program atau penerima manfaat saja. Hasil ujicoba tersebut diharapkan dapat dijadikan model penerapan sistem audit untuk program-program layanan kesejahteraan sosial lainnya.

Berdasarkan kesamaan persepsi tersebut selanjutnya tim pengkaji mendisain sistem audit sosial dengan tahapan sebagai berikut :

- Membangun kerangka dasar sistem audit sosial dan social accounting;

- Menyusun panduan, menetapkan kriteria dan indikator kinerja;

- Menyiapkan calon panel pakar dan tim penilai lapangan;

- Melakukan ujicoba sistem audit sosial dan social accounting;

- Menganalisis hasil ujicoba;

- Menyusun laporan hasil kajian.

\subsection{Penetapan Kriteria dan Indikator Kinerja}

Setelah melakukan penyamaan persepsi dan kajian secara mendalam, maka ditetapkan empat kriteria yang dianggap paling berpengaruh terhadap kinerja program pelayanan sosial yaitu: kriteria administrasi kegiatan, kriteria pelaksanaan kegiatan, kriteria hasil kegiatan dan kriteria dampak kegiatan. Secara rinci, komponen indikator untuk masing-masing kriteria tersebut adalah sebagai berikut:

A. Administrasi kegiatan, yang mencakup tiga indikator yakni :

1. Administrasi perencanaan kegiatan

2. Administrasi pelaksanaan kegiatan

3. Administrasi pelaporan

B. Pelaksanaan kegiatan, yang mencakup sembilan indikator yakni : 
1. Koordinasi antar pihak terkait dalam pelaksanaan kegiatan

2. Pendanaan kegiatan

3. Partisipasi peserta dalam kegiatan

4. Sistem monitoring dan evaluasi kegiatan

5. Penjadualan kegiatan

6. Rekruitmen

7. Sosialisasi

8. Training

9. Dukungan fasilitas

C. Hasil kegiatan, yang mencakup tujuh indikator yakni :

1. Tingkat ketercapaian hasil

2. Manfaat kegiatan bagi sasaran

3. Tingkat kepuasan penerima program

4. Persepsi masyarakat terhadap kegiatan

5. Persepsi penyelenggara kegiatan

6. Keberlanjutan dan kelestarian kegiatan

7. Permasalahan yang muncul akibat penyelenggaraan kegiatan

D. Dampak kegiatan, yang mencakup lima indikator yakni :

1. Kemandirian

2. Percaya diri

3. Gaya hidup

4. Jaringan sosial

5. Peningkatan ekonomi

Pada setiap kriteria dan indikator diberikan penjelasan mengenai pengertian indikator tersebut, jenis data dan informasi yang harus dikumpulkan untuk mendukung proses audit sosial, bagaimana cara melakukan verifikasi terhadap data dan informasi yang diperoleh, serta pemberian nilai atau skor dan bobot masing-masing indikator.

\subsection{Penyusunan Pedoman Pelaksanaan}

Dalam rangka pelaksanaan kegiatan audit sosial terhadap kinerja program pelayanan sosial perlu disusun pedoman pelaksanaan agar proses audit sosial tersebut dapat berlangsung secara sistematis dengan mengacu pada acuan yang standar, selanjutnya menjadi panduan bagi penilai lapangan dalam melaksanakan penilaian lapangan untuk proses audit sosial terhadap kinerja program pelayanan sosial yang dilaksanakan di Departemen Sosial.

Penilai lapangan diharapkan mampu mencari data dan informasi setiap program pelayanan sosial yang diamati untuk setiap indikator dengan mengacu pada metode verifikasi yang telah ditetapkan. Selanjutnya penilai lapangan memberikan nilai (skor) bagi setiap indikator dalam bentuk angka 5 (lima) untuk indikator dengan kondisi yang sangat baik sampai dengan angka 1 (satu) untuk kategori sangat buruk. Argumentasi pemberian nilai (skor) sangat baik, 
baik, sedang, buruk atau sangat buruk dicantumkan dengan jelas dalam laporan hasil penilaian lapangan. Untuk setiap indikator kemudian diberikan nilai akhir, yakni sebagai perkalian antara nilai (skor) hasil penilaian lapangan dengan nilai bobot yang telah ditetapkan.

Terhadap perolehan penilaian di lapangan kemudian dilakukan proses pengambilan keputusan audit sosial dengan mengacu kepada pedoman pengambilan keputusan. Keputusan yang dimaksud di sini adalah menetapkan apakah program pelayanan sosial yang diperiksa telah dikelola secara sangat baik, baik, sedang, buruk atau sangat buruk.

Pengambilan keputusan peringkat kinerja program pelayanan sosial terdiri atas:

a. Penetapan nilai (skor) setiap indikator

Setiap indikator ditetapkan nilai atau skornya sesuai dengan hasil penilaian di lapangan. Nilai atau skor terdiri dari 5 (lima) tingkat, yaitu sangat baik dengan nilai 5, baik dengan nilai 4 , sedang dengan nilai 3, buruk dengan nilai 4, dan sangat buruk dengan nilai 5. Alasan pemberian nilai atau skor tersebut pada masing-masing indikator dijelaskan secara tepat sesuai dengan temuan data dan fakta di lapangan.

b. Penetapan bobot (tingkat kepentingan) setiap indikator

Pada prinsipnya program pelayanan sosial dipengaruhi oleh berbagai faktor. Faktor-faktor yang dominan mempengaruhi keberhasilan program layanan sosial telah diidentifikasi dan diinventarisir berupa indikator, namun diduga setiap indikator pada program pelayanan sosial memiliki bobot atau tingkat kepentingan yang berbeda. Untuk mempermudah proses pengambilan keputusan telah ditetapkan bobot atau tingkat kepentingan setiap indikator, tetapi tidak menutup kemungkinan bobot tersebut diubah sesuai dengan kondisi dan hasil kajian/penilaian di lapangan. Setiap indikator memiliki bobot masing-masing dan apabila dijumlahkan keseluruhannya untuk 24 indikator jumlah bobotnya adalah 100 .

c. Perhitungan nilai akhir

Nilai akhir kinerja tiap indikator adalah perkalian nilai (skor) dengan bobot (tingkat kepentingan) sebagaimana dimaksud dalam pedoman pelaksanaan penilaian lapangan.

Nilai akhir kinerja program pelayanan sosial adalah jumlah nilai akhir kinerja dari 24 indikator. Nilai akhir yang tertinggi akan diperoleh seandainya semua indikator berada pada kondisi yang sangat baik sesuai dengan bobot (nilai kepentingan) masing-masing indikator, sehingga nilai akhir kinerja program pelayanan sosial tertinggi adalah $5 \times 100=500$, sementara nilai akhir terendah adalah $1 \times 100=100$. Peringkat kinerja program pelayanan sosial dapat dikelompokkan menjadi 5 kategori berdasarkan ketercapaian nilai akhir kinerja dengan klasifikasi sebagai berikut : 
$420-500=$ kinerja program tergolong sangat baik

$340-419=$ kinerja program tergolong baik

$260-339=$ kinerja program tergolong sedang

$180-259=$ kinerja program tergolong buruk

$100-179=$ kinerja program tergolong sangat buruk.

\subsection{Persiapan Pengumpulan Data}

Dalam rangka mendukung kelancaran ujicoba sistem audit sosial yang telah dikembangkan, pada saat ujicoba di lapangan dilakukan pula pengumpulan data dengan menggunakan instrumen yang berupa kuesioner. Dalam hal ini telah dibuat beberapa macam kuesioner, yaitu kuesioner untuk pengelola program, kuesioner untuk peserta program, kuesioner untuk rumah tangga peserta, kuesioner untuk tokoh masyarakat dan organisasi setempat.

Pengembangan instrumen pengumpul data tersebut telah melalui beberapa tahapan dengan mengacu kepada kisi-kisi sesuai dengan kriteria/indikator dalam sistem audit sosial. Validasi secara teoritik dan face validity terhadap instrumen telah dilakukan beberapa kali dengan sesama pendisain sistem dan stakeholder yang berkepentingan. Setelah melalui beberapa koreksi perbaikan selanjutnya dilakukan revisi instrumen, sehingga tersusunlah instrumen pengumpul data yang final.

Kegiatan pengumpulan data menggunakan instrumen final yang telah mengalami perbaikan atau penyempurnaan, baik dari segi substansi maupun bentuk atau formatnya. Kegiatan pengumpulan data dilakukan terhadap beberapa kelompok sasaran atau responden sesuai dengan yang telah direncanakan.

\subsection{Penyiapan Panel Pakar Dan Penilai Lapangan}

Kegiatan audit sosial memerlukan panel pakar dan penilai lapangan. Panel pakar bertugas dalam proses pengambilan keputusan terhadap kegiatan audit sosial, sedangkan penilai lapangan bertugas mengumpulkan data dan informasi yang terkait dengan kegiatan audit sosial, kemudian menyajikannya dalam bentuk laporan sehingga dapat digunakan sebagai bahan untuk pengambilan keputusan pada kegiatan audit sosial.

Pada tahap ujicoba sistem audit sosial, peran panel pakar dilakukan oleh para tenaga ahli yang mendisain dan mengkaji sistem. Penilai lapangan adalah tim asisten ahli yang akan membantu pengumpulan data di lapangan. Pada saat implementasi sistem audit sosial nantinya, panel pakar dan penilai lapangan perlu dibentuk secara khusus dengan ketetapan tersendiri.

Penilaian lapangan harus cermat dan tepat sehingga data dan informasi yang dikumpulkan seakurat mungkin sehingga diperlukan tenaga ahli yang berkompeten yakni yang mampu mengumpulkan data dan informasi 
pendukung secara utuh. Oleh karena itu, sebelum pengumpulan data di lapangan dilakukan pelatihan (coaching) bagi seluruh tim pelaksana.

Tugas penilai lapangan antara lain :

- Menyusun rencana kerja penilaian lapangan

- Mempresentasikan dan mendiskusikan rencana kerja dengan tenaga ahli

- Menghimpun data primer dan sekunder yang diperlukan sesuai pedoman audit sosial

- Melakukan analisis dan menarik kesimpulan untuk setiap indikator berdasarkan data/informasi yang dihimpun di lapangan

- Menyusun laporan tertulis secara sistematis

- Menyajikan/mempresentasikan laporan hasil penilaian lapangan kepada tenaga ahli.

Adapun tugas panel pakar antara lain :

- Mempelajari informasi mengenai program layanan sosial hasil penilaian lapangan

- Melakukan penilaian terhadap setiap indikator

- Melakukan perhitungan total nilai akhir setiap program layanan sosial yang dinilai

- Menentukan kategori peringkat kinerja program layanan sosial yang diaudit.

\section{Hasil dan Pembahasan}

\subsection{Gambaran Program Pembangunan Kesejahteraan Sosial}

Sejak adanya krisis ekonomi yang berkepanjangan jumlah penduduk miskin di Indonesia terus bertambah. Menurut data BPS (2003) penduduk miskin di Indonesia berjumlah 40 juta jiwa dan diperkirakan jumlah penduduk miskin akan meningkat secara signifikan pada beberapa tahun mendatang mengingat adanya kenaikan biaya hidup. Keadaan kemiskinan dapat ditandai dengan kerentanan, ketidakberdayaan, keterisolasian, dan ketidakmampuan untuk menyampaikan aspirasi. Kondisi tersebut diantaranya mengakibatkan tingginya beban ekonomi masyarakat, rendahnya partisipasi masyarakat, menurunnya ketertiban umum dan ketentraman masyarakat, dan menurunnya kepercayaan masyarakat terhadap birokrasi dalam memberikan pelayanan kepada masyarakat (Departemen Sosial RI, 2004).

Keadaan tersebut di atas merupakan tantangan berat bagi bangsa Indonesia, khususnya Departemen Sosial untuk mewujudkan visi "kesejahteraan sosial untuk semua". Artinya bahwa setiap anggota masyarakat atau seluruh warga negara berhak dan memerlukan taraf kesejahteraan sosial yang sebaik-baiknya atau yang layak bagi kemanusiaan, akan tetapi juga berkewajiban untuk ikut serta dalam mewujudkan kesejahteraan dan kemakmuran bersama. 
Pembangunan bidang kesejahteraan sosial adalah pembangunan manusia dan lingkungan sosial dengan segala kompleksitas dan implikasinya, yang memiliki kekhususan ciri sasaran pelayanan dan penanganan tersendiri. Fokus sasarannya diarahkan pada pembangunan sumberdaya bidang kesejahteraan sosial sebaik-baiknya serta penciptaan lingkungan sosial masyarakat yang sehat dan dinamis. Pembangunan bidang kesejahteraan sosial merupakan upaya untuk mengembangkan kemampuan masyarakat agar dapat memenuhi kebutuhan dasar dengan mendayagunakan potensi dan sumber kesejahteraan sosial yang ada di lingkungan yang bertumpu pada pemberdayaan kemampuan masyarakat sehingga masyarakat siap untuk berperan serta (Departemen Sosial RI, 2004).

Dalam mainstream Departemen Sosial Republik Indonesia, terdapat dua sasaran pembangunan kesejahteraan sosial yaitu PMKS dan Potensi dan Sumber Kesejahteraan Sosial (PSKS). PMKS adalah masyarakat yang mengalami nasib kurang beruntung, baik fisik maupun sosialnya. Berdasarkan data tahun 2003 dan tahun 2004 jumlah PMKS di seluruh Indonesia meningkat tajam. Sedangkan PSKS adalah semua hal yang berharga yang dapat digunakan untuk menjaga, menciptakan, mendukung atau memperkuat Usaha Kesejahteraan Sosial (UKS); atau masyarakat yang mampu dalam upaya penanganan masalah kesejahteraan sosial. PSKS dapat berasal atau bersifat manusiawi, sosial, dan alam. Berbagai kegiatan pembangunan kesejahteraan sosial bagi para PMKS di lapangan antara lain diorganisir dalam berbagai bentuk program seperti: Kelompok Usaha Bersama (KUBE), Balai-Balai Rehabilitasi Sosial, Rumah Singgah, Panti Jompo dan lain-lain yang sebagian besar juga terintegrasi dalam program-program kemasyarakatan dan kemanusiaan pada tingkat desa. Bahkan sedang diupayakan pula terbentuknya forum bagi setiap UKS sebagai wadah komunikasi penanggulangan masalah-masalah kesejahteraan sosial yaitu Wahana Kesejahteraan Sosial Berbasis Masyarakat (WKSBM).

Dari data tersebut terlihat bahwa secara keseluruhan jumlah PMKS meningkat dari tahun 2003 ke tahun 2004 meskipun perilaku perubahan setiap PMKS berbeda satu sama lain. Jika diperhatikan kategori PMKS dapat dikelompokkan menjadi:

(i) Kelompok Umur: anak, dewasa dan usia lanjut,

(ii) Kelompok Jenis Kelamin: laki-laki dan perempuan,

(iii) Kelompok satuan warga: individu, keluarga dan komunitas.

Perbedaan kategori tersebut menjadi acuan dalam melakukan analisis pada tingkat nasional disamping analisis pada satuan-satuan program yang diambil sebagai sampel. Sampel yang dianalisis merupakan representasi dari kategori kelompok PMKS, yang kemungkinan variasi dari setiap kabupaten/kota adalah sebagai berikut:

(i) Program untuk anak jalanan/anak terlantar (ANJAL/AT)

(ii) Program untuk wanita rawan sosial ekonomi (WRSE)

(iii) Program untuk lanjut usia terlantar (LUT) 
(iv) Program untuk keluarga fakir miskin (KFM)

(v) Program untuk keluarga bagi rumah tidak layak huni (RTLH)

(vi) Korban bencana alam (KBA).

Tabel 5. Gambaran Umum PMKS di Indonesia Tahun 2003 - 2004

\begin{tabular}{|c|l|r|r|}
\hline \multirow{2}{*}{ No } & \multicolumn{1}{|c|}{ Jenis PMKS } & \multicolumn{2}{|c|}{ Jumlah } \\
\cline { 3 - 4 } & & \multicolumn{1}{|c|}{$\mathbf{2 0 0 3}$} & \multicolumn{1}{|c|}{$\mathbf{2 0 0 4}$} \\
\hline 1 & Anak Balita Terlantar & 1.178 .824 & 1.138 .126 \\
2 & Anak Telantar & 3.461 .309 & 3.308 .642 \\
3 & Anak yang menjadi TKT atau diperlakukan salah & 43.708 & 48.526 \\
4 & Anak Nakal & 193.115 & 189.075 \\
5 & Anak Jalanan & 90.210 & 98.113 \\
6 & Anak Cacat & 367.520 & 365.868 \\
7 & Wanita Rawan Sosial Ekonomi & 1.449 .203 & 1.253 .921 \\
8 & Wanita Yg Menjadi KTK/Diperlakukan Salah & 28.562 & 42.844 \\
9 & Lanjut Usia Terlantar & 2.848 .854 & 3.092 .910 \\
10 & Lanjut Usia yang Menjadi KTK/Diperlakukan Salah & 10.727 & 11.689 \\
11 & Penyandang Cacat & 1.673 .119 & 1.847 .692 \\
12 & Penyandang Cacat Bekas Penderita Penyakit Kronis & 215.543 & 216.148 \\
13 & Tuna Susila & 83.386 & 59.051 \\
14 & Pengemis & 27.625 & 87.536 \\
15 & Gelandangan & 57.669 & 28.305 \\
16 & Bekas Narapidana & 115.307 & 118.183 \\
17 & Korban Penyalahgunaan Napza & 23.660 & 245.774 \\
18 & Keluarga Fakir Miskin & 16.689 .773 & 14.807 .332 \\
19 & Keluarga Berumah Tak layak Huni & 5.165 .055 & 6.525 .947 \\
20 & Keluarga Bermasalah Sosial Psikologis & 188.385 & 195.474 \\
21 & Komunitas Adat Terpencil & 233.858 & 267.795 \\
22 & Masyarakat Tinggal di Daerah Rawan Bencana & 1.628 .626 & 2.075 .116 \\
23 & Korban Bencana Alam & 1.268 .766 & 1.139 .363 \\
24 & Korban Bencana Sosial/Pengungsi & 850.432 & 654.952 \\
25 & Pekerja Migran Terlantar & 1.885 & 45.375 \\
26 & Pengidap HIV/AIDS & 2.941 & 5.560 \\
27 & Keluarga Rentan & 1.829 .235 & 1.926 .210 \\
\hline
\end{tabular}

Dari keenam program tersebut di atas dipilih tiga program unggulan pada setiap kabupaten/kota untuk dijadikan sampel penelitian. Secara kebetulan bahwa keenam program tersebut di atas merupakan jenis PMKS terbesar secara nasional.

Pada setiap wilayah komunitas program PMKS tersebut dikaji juga peran PSKS dalam mendukung program PMKS. Berdasarkan data Departemen Sosial RI tahun 2004, terdapat tiga kategori PSKS yaitu: organisasi sosial operasional (organisasi yang langsung memberikan pelayanan kepada UKS), organisasi sosial koordinatif Tingkat Kabupaten, organisasi sosial koordinatif 
tingkat provinsi, organisasi Karang Taruna dan Pekerja Sosial Masyarakat (PSM).

\subsection{Kinerja Program Layanan Sosial}

Kinerja program layanan sosial bervariasi antara satu daerah atau lokasi dengan daerah atau lokasi lainnya. Berdasarkan hasil ujicoba pengembangan sistem audit sosial maka kinerja 21 program layanan sosial yang diamati dapat dikategorikan seperti berikut ini :

a. Program dengan kinerja sangat baik

$$
\begin{aligned}
& =0 \operatorname{program}(0 \%) \\
& =9 \operatorname{program}(42,86 \%) \\
& =10 \operatorname{program}(47,62 \%) \\
& =1 \operatorname{program}(4,77 \%) \\
& =1 \operatorname{program}(4,77 \%) .
\end{aligned}
$$

b. Program dengan kinerja baik

c. Program dengan kinerja sedang

d. Program dengan kinerja buruk

Di antara program layanan sosial yang diamati dalam kegiatan audit sosial, kinerja program yang paling baik yakni dengan skor paling tinggi adalah program penanganan penyandang cacat (PACA) di Provinsi Jawa Tengah dengan skor total 409 (kategori baik) dengan rataan skor sebesar 17,04; sedangkan skor paling rendah terjadi pada program penanganan lanjut usia terlantar (LUT) di Provinsi Sulawesi Tenggara dengan skor total 171 (kategori sangat buruk) dengan rataan skor sebesar 7,125.

Jika ditinjau dari skor tiap indikator secara nasional, rataan skor indikator adalah sebesar 13,70. Skor rataan tertinggi terjadi pada indikator 2.3 (partisipasi peserta dalam kegiatan) dengan skor mencapai 17,62 sedangkan rataan terendah terjadi pada indikator 2.8 (training) dengan skor mencapai 10,10. Kinerja masing-masing program yang ditunjukkan dengan skor total dapat dilihat pada Gambar 2.

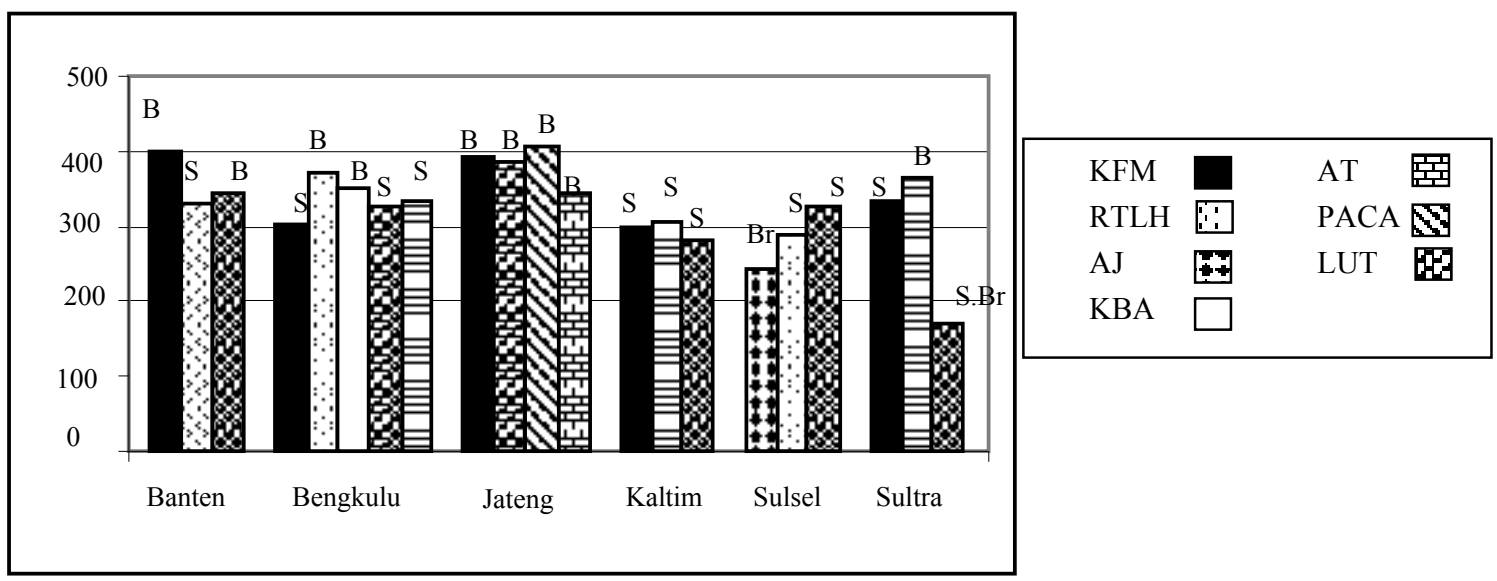

Gambar 2. Skor Indikator Kinerja Program Pelayanan Sosial Pada Enam Provinsi 
Kinerja program layanan sosial yang diamati di Provinsi Banten, dengan skor paling tinggi adalah program penanganan KFM dengan skor total 400 (kategori baik) dengan rataan skor sebesar 16,67; sedangkan skor paling rendah terjadi pada program penanganan rumah tidak layak huni (RTLH) dengan skor total 332 (kategori sedang) rataan skor sebesar 13,83. Rataan skor indikator 14,92. Skor tertinggi pada indikator 3.6 (keberlanjutan dan kelestarian kegiatan) program penanganan LUT mencapai 25, skor terendah pada indikator 2.8 (training) dan 4.4 (jaringan sosial) program penanganan RTLH mencapai 4. Kinerja program pelayanan sosial Provinsi Banten pada Gambar 3.

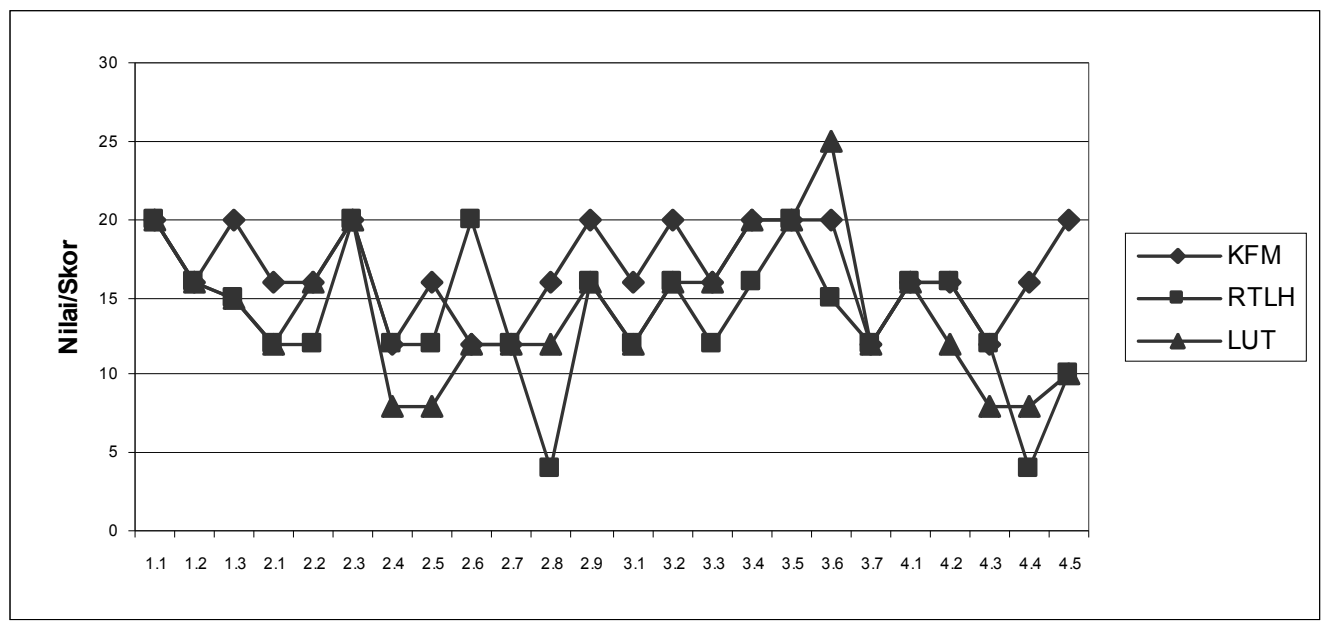

Gambar 3. Kinerja Program Pelayanan Sosial Provinsi Banten

Kinerja program layanan sosial di Provinsi Bengkulu dengan skor paling tinggi adalah program penanganan rumah tidak layak huni (RTLH) dengan skor total 369 (kategori baik) dengan rataan skor sebesar 15,38; sedangkan skor paling rendah terjadi pada program penanganan keluarga fakir miskin (KFM) dengan skor total 304 (kategori sedang) dengan rataan skor sebesar 12,67. Jika ditinjau dari skor tiap indikator rataan skor indikator adalah sebesar 13,33.

Skor indikator tertinggi terjadi pada indikator 2.3 (partisipasi peserta dalam kegiatan) dan indikator 3.5 (persepsi penyelenggara kegiatan) pada hampir seluruh program penanganan sosial dengan skor mencapai 20, sedangkan skor indikator terendah terjadi pada indikator 3.1 (tingkat ketercapaian hasil) pada program penanganan KFM dengan skor mencapai 4. Kinerja masing-masing program pelayanan sosial di Provinsi Bengkulu yang ditunjukkan dengan skor masing-masing indikator dapat dilihat pada Gambar 4. 


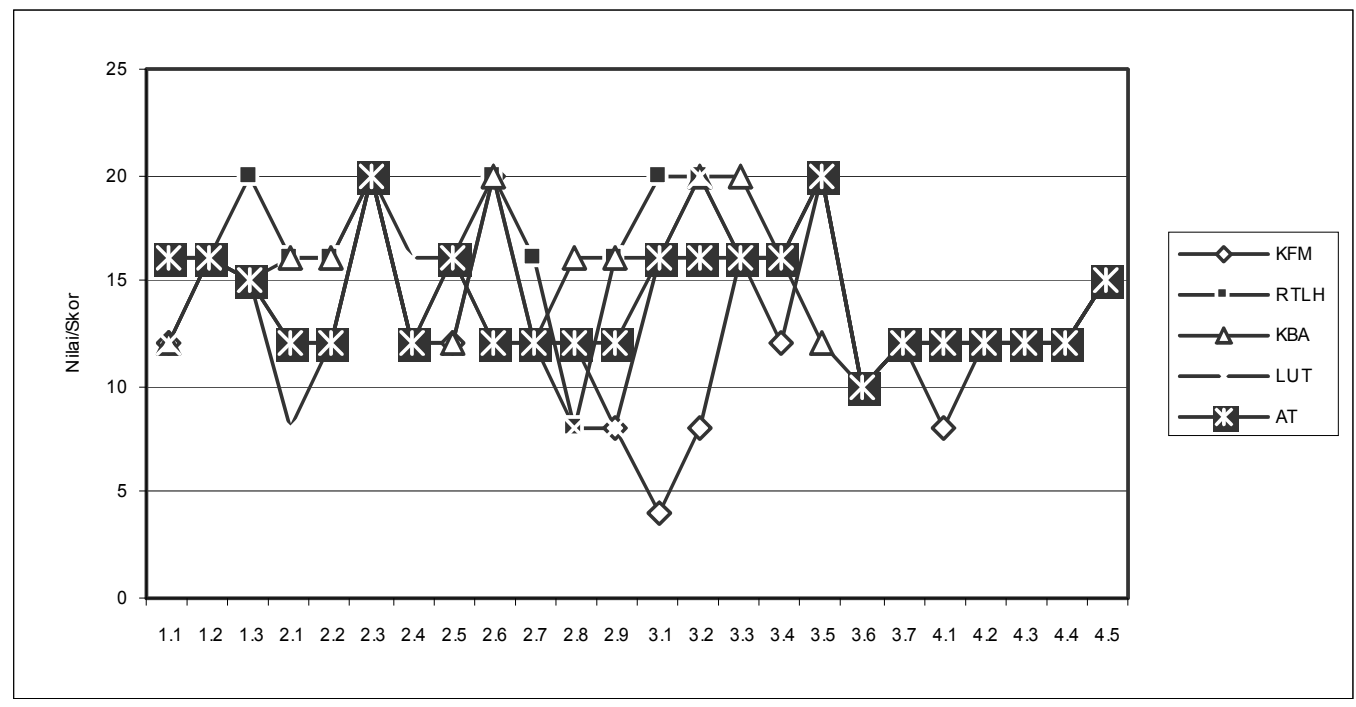

Gambar 4. Kinerja Program Pelayanan Sosial Provinsi Bengkulu

Kinerja program layanan sosial yang diamati dalam kegiatan audit sosial di Provinsi Jawa Tengah, dengan skor paling tinggi adalah program penanganan penyandang cacat (PACA) dengan skor total 409 (kategori baik) rataan skor sebesar 17,04; sedangkan skor paling rendah pada program penanganan keluarga fakir miskin (KFM) skor total 344 (kategori sedang) rataan skor 14,33. Jika ditinjau dari skor tiap indikator yang diamati di Provinsi Jawa Tengah, rataan skor indikator adalah sebesar 15,93. Skor indikator tertinggi terjadi pada indikator 2.3 (partisipasi peserta dalam kegiatan) pada seluruh program penanganan sosial dan indikator 3.6 (keberlanjutan dan kelestarian kegiatan) pada program AT dan LUT dengan skor mencapai 25, sedangkan skor indikator terendah terjadi pada indikator 2.8 (training) pada program penanganan AT dan LUT dengan skor mencapai 4. 


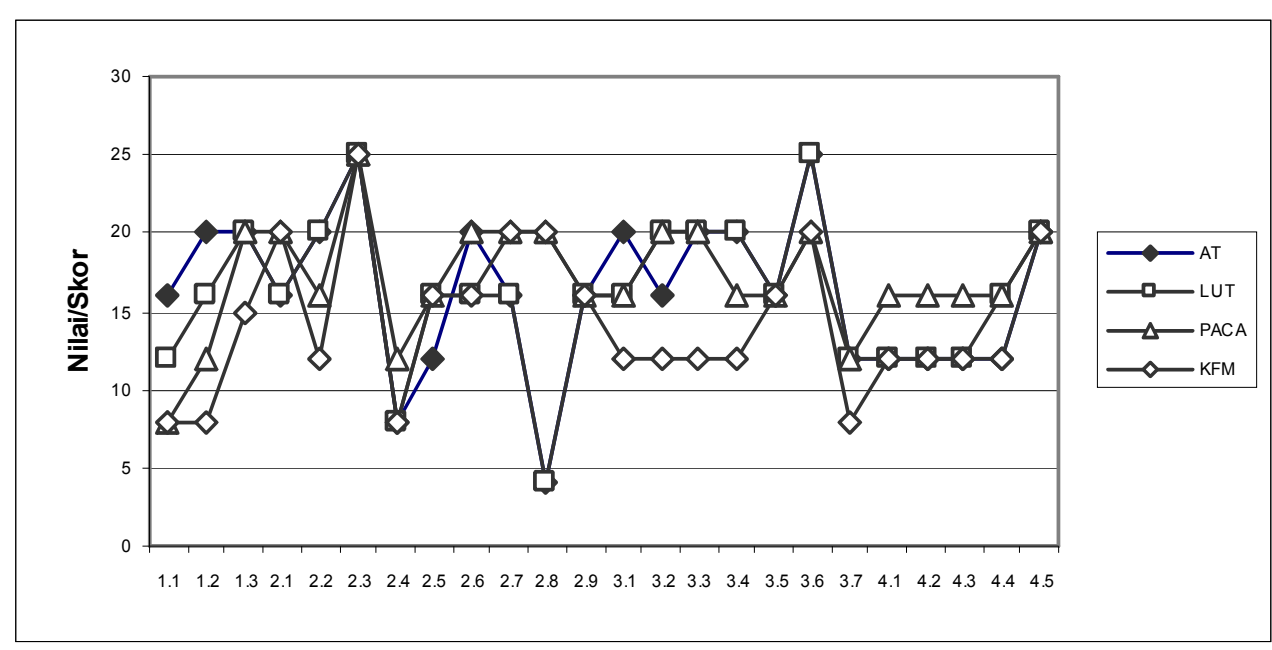

Gambar 5. Kinerja Program Pelayanan Sosial Provinsi Jawa Tengah

Kinerja program layanan sosial yang diamati dalam kegiatan audit sosial di Provinsi Kalimantan Timur dengan skor paling tinggi adalah program penanganan anak terlantar (AT) dengan skor total 305 (kategori sedang) rataan skor sebesar 12,71; skor paling rendah terjadi pada program penanganan lanjut usia terlantar (LUT) skor total 283 (kategori sedang) rataan skor sebesar 11,79. Jika ditinjau dari skor tiap indikator yang diamati di Provinsi Kalimantan Timur, rataan skor indikator adalah sebesar 12,33. Skor indikator tertinggi terjadi pada indikator 2.3 (partisipasi peserta dalam kegiatan), indikator 3.2 (manfaat kegiatan bagi sasaran) dan 3.5 (persepsi penyelenggara kegiatan) pada program penanganan KFM dengan skor mencapai 20, sedangkan skor indikator terendah terjadi pada indikator 2.5 (penjadwalan kegiatan) pada program penanganan KFM dan LUT dengan skor mencapai 4. Kinerja masing-masing program pelayanan sosial di Provinsi Kalimantan Timur yang ditunjukkan dengan skor masing-masing indikator dapat dilihat pada Gambar 6. 


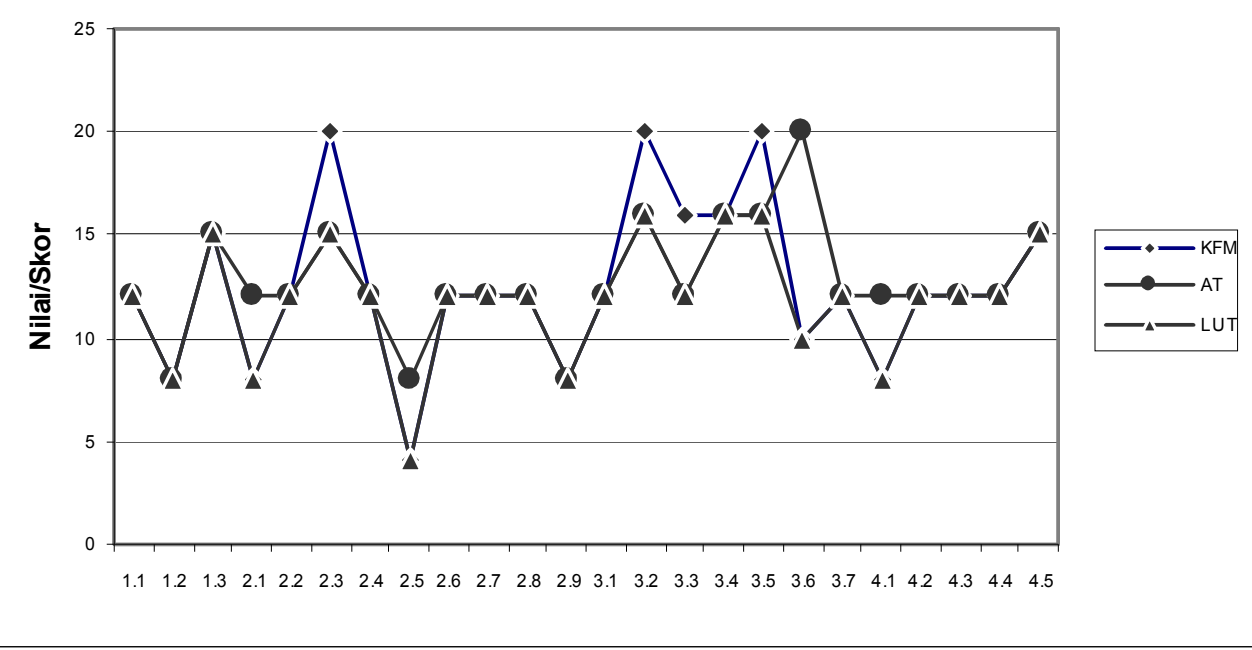

Gambar 6. Kinerja Program Pelayanan Sosial Provinsi Kalimantan Timur

Kinerja program layanan sosial yang diamati dalam kegiatan audit sosial di Provinsi Sulawesi Selatan, kinerja program yang paling baik yakni dengan skor paling tinggi adalah program penanganan lanjut usia terlantar (LUT) dengan skor total 328 (kategori sedang) dengan rataan skor sebesar 13,67; sedangkan skor paling rendah terjadi pada program penanganan anak jalanan/terlantar (AJ) dengan skor total 242 (kategori buruk) dengan rataan skor sebesar 10,80 .

Jika ditinjau dari skor tiap indikator yang diamati di Provinsi Sulawesi Selatan, rataan skor indikator adalah sebesar 11,89 . Skor indikator tertinggi terjadi pada indikator 3.6 (keberlanjutan dan kelestarian kegiatan) dan indikator 4.5 (peningkatan ekonomi) pada program penanganan LUT dengan skor mencapai 25, sedangkan skor indikator terendah terjadi terutama pada indikator 2.4 (sistem moneva kegiatan) untuk seluruh program penanganan sosial dengan skor mencapai 4 . Kinerja masingmasing program pelayanan sosial di Provinsi Sulawesi Selatan yang ditunjukkan dengan skor masing-masing indikator dapat dilihat pada Gambar 7. 


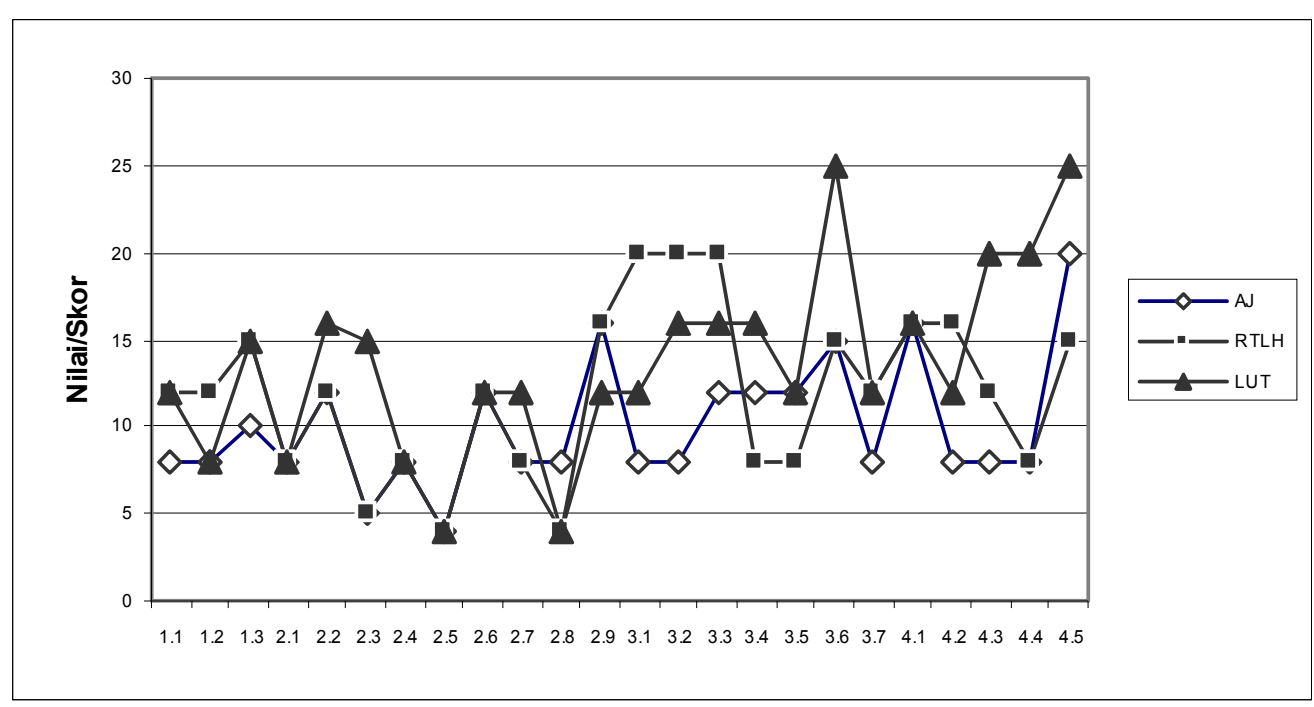

Gambar 7. Kinerja Program Pelayanan Sosial Provinsi Sulawesi Selatan

Kinerja program layanan sosial yang diamati dalam kegiatan audit sosial di Provinsi Sulawesi Tenggara dengan skor paling tinggi adalah program penanganan anak terlantar (AT) dengan skor total 364 (kategori baik) dengan rataan skor sebesar 15,17; sedangkan skor paling rendah terjadi pada program penanganan lanjut usia terlantar (LUT) dengan skor total 171 (kategori sangat buruk) dengan rataan skor sebesar 7,13.

Jika ditinjau dari skor tiap indikator yang diamati di Provinsi Sulawesi Tenggara, rataan skor indikator adalah sebesar 12,07. Skor indikator tertinggi terjadi pada indikator 1.3 (administrasi pelaporan) dan indikator 3.6 (keberlanjutan dan kelestarian kegiatan) pada program penanganan AT dengan skor mencapai 25 , sedangkan skor indikator terendah terjadi pada beberapa indikator untuk program penanganan lanjut usia terlantar (LUT) dengan skor mencapai 4. Kinerja masing-masing program pelayanan sosial di Provinsi Sulawesi Tenggara yang ditunjukkan dengan skor masing-masing indikator dapat dilihat pada Gambar 8. 

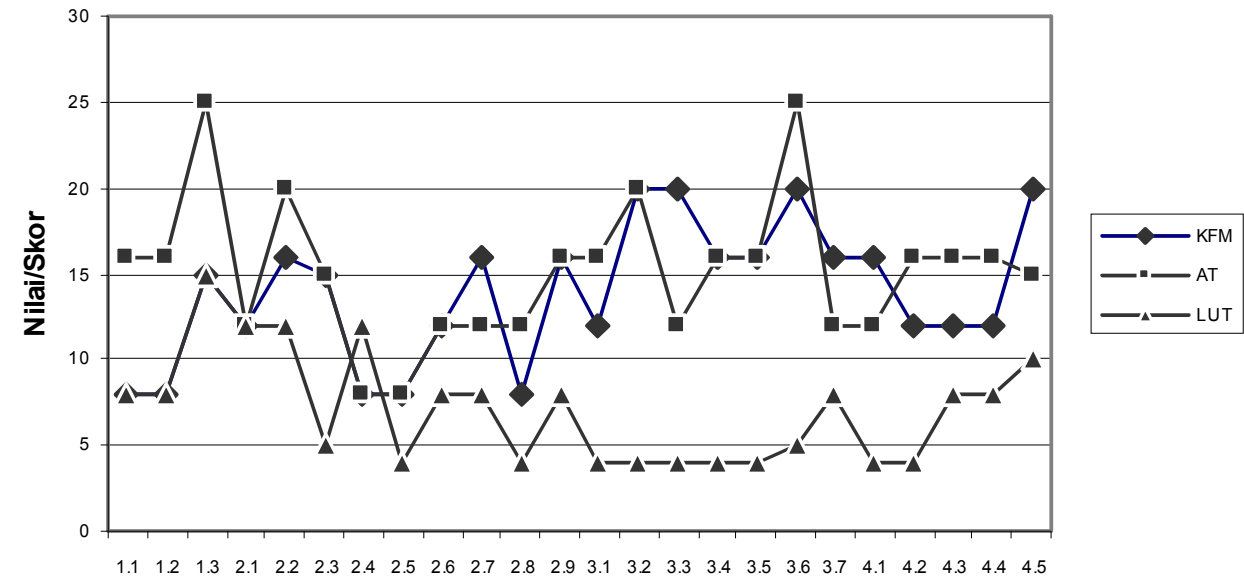

Gambar 8. Kinerja Program Pelayanan Sosial Provinsi Sulawesi Tenggara

\section{Kesimpulan dan Saran}

\subsection{Kesimpulan}

Berdasarkan hasil analisis terhadap pengembangan sistem audit sosial serta analisis terhadap hasil ujicoba sistem tersebut yang didukung dengan data kuantitatif dan data kualitatif, maka dapat disimpulkan beberapa hal sebagai berikut :

1. Kinerja program layanan sosial bervariasi antara satu daerah atau lokasi dengan daerah atau lokasi lainnya. Berdasarkan hasil ujicoba pengembangan sistem audit sosial maka kinerja 21 program layanan sosial yang diamati dapat dikategorikan seperti berikut ini :
a. Program dengan kinerja sangat baik
$=0 \operatorname{program}(0 \%)$
b. Program dengan kinerja baik
$=9 \operatorname{program}(42,86 \%)$
c. Program dengan kinerja sedang
$=10$ program $(47,62 \%)$
d. Program dengan kinerja buruk
$=1 \operatorname{program}(4,77 \%)$
e. Program dengan kinerja sangat buruk
$=1$ program $(4,77 \%)$.

2. Di antara program layanan sosial yang diamati dalam kegiatan audit sosial, kinerja program yang paling baik yakni dengan skor paling tinggi adalah program penanganan penyandang cacat (PACA) di Provinsi Jawa Tengah dengan skor total 409 (kategori baik) dengan rataan skor sebesar 17,04; sedangkan skor paling rendah terjadi pada program penanganan lanjut usia terlantar (LUT) di Provinsi Sulawesi Tenggara dengan skor total 171 (kategori sangat buruk) dengan rataan skor sebesar 7,13 .

3. Terdapat kecenderungan program layanan sosial dinas sosial provinsi dan kabupaten/kota dianggap sebagai warisan pengelola sebelumnya dan tidak ada terobosan untuk menemukan jenis PMKS baru. 
4. Sebagian program tepat sasaran sehingga manfaatnya dapat dirasakan oleh PMKS, namun gagal membangun mekanisme pelaksanaan proyek sehingga program tidak berlanjut atau masyarakat melakukan copy pasting mechanism.

5. Dalam pelaksanaan rekruitmen peserta program layanan sosial masih dijumpai adanya rekruitmen atau pemilihan sasaran yang bersifat penunjukan langsung berdasarkan pertimbangan subyektif.

6. Dalam mengelola program layanan sosial masih dijumpai adanya kecenderungan "bersaing" antara dinas provinsi dan kabupaten/kota sehingga penanganan program layanan sosial tersebut tidak tertangani secara komprehensif, efektif dan efisien karena dampak dari adanya "tarik menarik" atau "acuh tak acuh" terhadap pengelolaan program yang bersangkutan.

\subsection{Saran}

Mengacu pada analisis hasil ujicoba pengembangan sistem audit sosial untuk program layanan sosial Departemen Sosial RI, berikut ini disajikan beberapa saran untuk pengembangan sistem audit sosial di kemudian hari, di antaranya :

1. Untuk memudahkan penetapan kriteria dan indikator sistem audit sosial, perlu ada re-grouping PMKS guna mempermudah analisis dan penyajian hasil audit. Pola regrouping dapat dilakukan berdasarkan kesamaan karakteristik aktivitas PMKS, dan/atau variabel penentu kesejahteraan sosial. Dengan cara ini diharapkan dapat mempertajam analisis kinerja.

2. Dalam rangka implementasi sistem audit sosial pada seluruh program layanan sosial yang dikelola oleh Departemen Sosial, perlu dilakukan evaluasi periodik terhadap sistem audit yang telah dikembangkan dengan melibatkan stakeholders. Evaluasi tersebut dapat berkaitan dengan kerangka dasar sistem audit itu sendiri, jenis kriteria dan indikator yang diamati, penentuan bobot tiap indikator, teknik pengumpulan data, cara pengambilan keputusan audit sosial, cara penulisan laporan, mekanisme klaim terhadap hasil audit, publikasi hasil audit, dan sebagainya. Kerangka sistem audit hasil kajian ini tidak dapat digunakan secara intens, melainkan harus lebih dioperasionalkan sesuai dengan pola regrouping yang diterapkan, dan memperhatikan konteks lokal PMKS.

3. Perlu dilakukan sosialisasi kepada stakeholders dan semua pihak berkenaan dengan pentingnya audit sosial dalam program layanan sosial, beserta ukuran-ukurannya.

4. Untuk mendukung implementasi sistem audit sosial perlu dikeluarkan seperangkat regulasi di tingkat kementrian berupa Keppmen, sehingga penerapan sistem audit sosial lebih bersifat mengikat dan pedoman operasional atau pedoman teknis terkait.

5. Perlu upaya pengembangan sumberdaya manusia yang akan mengelola sistem audit sosial tersebut pada lingkup dinas sosial provinsi atau kab/kota dan PSKS/komunitas, misalnya melalui pendidikan dan pelatihan, workshop, seminar, dan sebagainya. 


\section{Daftar Pustaka}

Anonim. Audit Sosial Pembangunan: Pengalaman di Malaysia dan Indonesia di Era Otonomi Daerah. Bandung: FISIP UNPAD, 2005.

Anonim. Pembangunan dan Audit Sosial: Masalah dan Strategi di Indonesia. Kuala Lumpur: Universitas Malaya, 2002.

Boyd, Graham. Social Auditing - A Method of Determining Impact. Alana Albee Consultants and Associates, (http://www.caledonia.org.uk/socialland/social.htm), 14 January 1998.

Cox, Eva. The Social Audit Cookbook: recipes for auditing the way we connect. Sydney: Lance Reichstein Foundation, 2002.

Departemen Sosial RI. Pengumpulan dan Pengolahan Data Kebijakan Pemda mengenai Pembangunan Kessos: Survey pada 60 Kabupaten/Kota di 30 Provinsi. Jakarta: Pusdatin Kessos, 2004.

Department of Health, Social Services and Public Safety. Research into Substance Misuse and Homelessness. Nortern Ireland: Council for the Homeless, 2003.

Edwards, R.W. Measuring Social Capital: an Australian Framework and Indicators. Information Paper. Canberra: Australian Bureau of Statistics, 2004. 